\title{
The Impact of Remittances on Children Educational Outcome in Indonesia
}

\author{
Pratiwi Indri Hapsari ${ }^{1}$ \\ University of Indonesia and International University of Japan
}

\begin{abstract}
This study investigated the impact of remittances on education outcome of children in migrant household using cross-sectional data from ongoing longitudinal survey International Family Life Survey fifth wave that collected in 2014. The study controls household's characteristics and individual characteristics and endogeneity problem using Instrumental Variables estimation. This research using Instrumental Variable Probit Estimation. The remittance is the main variable and the married status, sex category, age of household's head, household's head education, and wealth as control variable. This research finds that remittance has negative and significant effect on probability of having higher education on children in migrant households.
\end{abstract}

Keywords: remittances; children of migrant household; higher education; IFLS; Intrumental Variable-probit estimation

\footnotetext{
${ }^{1}$ Pratiwi Indri Hapsari is a student at Economic Faculty, University of Indonesia - Graduate School of
} International Relation, International University of Japan. E-mail: pratiwiindrihapsari@yahoo.com 


\title{
The Impact of Remittances on Children Educational Outcome in Indonesia
}

\author{
Pratiwi Indri Hapsari
}

\section{Introduction}

In most developing countries, including Indonesia, people are trying to obtain better economic opportunities by migrating to another place, either within the country or outside the country. There are two types of migration that Indonesian people experience. The first type is the internal migration, which refers to the process of moving from one region to other region within the country. Second type is international migrant, which refer to someone that moving outside his or her home countries. Both of the migrants have the same reason which is economic reason. It means, they migrated out of their origin place to have better income (Adams \& Page, 2005). Todaro (1969) also stated that migration occurs based on an individual's expectation that they will have a higher salary in the new place by finding a new job. Furthermore, it also believed that migration will have more benefits for the migrant people rather than staying in the original place (Resosudarmo \& Suryadarma, 2014).

In terms of migration for economic purposes, a migrant hopes to earn money in their destination. The migrant worker will not use the money most likely, but instead the money will be sent to the migrant's household in their place of origin. The money or goods that are transferred by migrant workers to the migrant's household located in their place of origin, either from abroad or their migrant destinations, are called remittances (Adams, 1991). Remittance in Indonesia plays a very important role because, for a developing country such as Indonesia, remittance is one of the main resources of income to be used for investment in education and health in the place of origin of the migrant worker. Remittances also have an important role in alleviating people from poverty and increasing economic growth in Indonesia ("IFAD in Indonesia," n.d.).

Furthermore, remittance is the second biggest financial external input in the Indonesian GDP after external debt. In 2005, more than US\$2.384 million flowed into the Indonesian GDP from international remittances ("Indonesia Remittances | 2005-2017 | Data | Chart | Calendar | Forecast," n.d.) Data shows that, of 40 million people who lived in municipalities in 2005, 16 million were long-term migrants (35\%) from rural areas.

In previous studies, the positive impact of remittances has been found. The positive impacts of remittances involve loosening budget constraints for the households of migrant workers. Increasing household incomes lead to optimal 
conditions for the education of the children in the household. Several studies support this argument. Hill \& Duncan (1987) found that a 10\% increase in the income of a household would increase the number of years of schooling for children by maximum $1 \%$. Blau (1999) also discovered that an increase in family income increases the mathematics and verbal score of children whose family experienced increased income.

However, there is a difference between remittances and regular financial transfers. The difference lies in the characteristics of remittances that are sent to the households of migrant workers. In the households of migrant workers, there is shift in the structure of household members. The absence of one (or both) parent might have a negative effect on the children living within such households. The absence of one (or both) parent may result in a larger opportunity cost for the members of the household. As a parent is usually the migrant worker, their absence from the family removes an important role in the developmental stages of the children in their households. When important members are missing (e.g., a family member leaves the household to become a migrant worker), the motivation of a child to study and succeed academically also decreases. As a result, the non-financial cost of a family member migrating to work might be higher than the financial benefits received by the households

The effects of remittances on education have been studied and provide several results. Most studies indicate that remittances have a positive impact on children's education. Edwards \& Ureta,(2003) in their study in the El Salvador, found that remittances from abroad had a positive impact on a student's length of study at school. Yang et al (2008) study concerning the Philippines, found that that expenditure on education is increasing because of better exchange rates for overseas' currency. As a result of these currency moves, more Filipinos are going aboard to work and are sending more money back to their families for their families' education. Hanson \& Woodruff (2003) stated that migration would add the length of education for girl at age 10-15 years old and boys at age 1315. Furthermore, Salas (2014) claimed that remittances will increase probability of having better education with their enrolment in private schools. This evidence about the positive income of remittances on children's education also is also supported by Edwards \& Ureta (2003) in their research. They found that remittances have a greater impact on children's education than doe's regular income on lowering the number of children who drop out of school. However, some studies also found negative impacts of remittances on the outcome of the education of children in a migrant household. Zhao, Yu, Wang, \& Glauben (2014) pointed out that the absence of one or both parents due to their migration has a negative impact on children's performance in school. The authors also stated that the children from households who receive remittances receive worse grades than children from households that do not receive remittances. When one or both parents are absent from the household, children's educational motivation 
is lost, and this is a negative impact of remittances in children's education. Moreover, studies from Mexico by McKenzie \& Rapoport (2011) found that the impact of remittances on the educational outcome of children left behind by migrant workers is large and negative. This means that, in households which receive remittances, the possibility of the children in the household dropping out of school increases. The negative impact of remittances on children's schooling involves the increasing the dropout rate of children from school. This is mainly due to the fact that children in migrant households are more likely to both migrate themselves and begin working, something which is less likely with children in non-migrant-worker households.

In Indonesia, studies about the impact of remittances on educational achievement indicate a positive impact. Nguyen \& Purnamasari (2011) conclude that international migration has a positive impact on reducing the number of children who drop out of school. In their research, it is explained that increasing income from migrant workers will decrease the number of children in labor and will increase their length of study at school. Nonetheless, the remittances fail to increase children's school enrolment due to the negative impact of their parents' absence for the reason of lack of supervision by parents who are absent due to their migration for work.

This research aims to bridge the gap between previous studies while observing the impact of remittances on educational outcome in Indonesian households. This study employed the newest wave of the Indonesia Life Family Survey (IFLS) that was collected in 2014. The specific purpose of this study is to provide valuable information about the impact of remittances on educational outcomes in Indonesia and enable policy makers in the Indonesian government to establish new policies to improve children's education in this country.

\section{Research Method}

\subsection{Data}

This paper employs IFLS data from the fifth wave survey that was conducted in 2014. This IFLS data consists of a sample of $80 \%$ of Indonesian households from 13 of the 26 provinces of Indonesia. The data were collected in late 2013 and early 2014, and consists of 44,103 individual observations that come from 13,535 households. This survey provides information about individuals, households and community service for the households.

The question about remittances, which is the main variable in this research, is not available in the survey question since the IFLS is not a survey that is focused on the migrant worker, even though there are some questions in the questionnaire that are related to migrant worker, but they have no relation with this remittance issue. Therefore, this paper uses two questions from different parts of the survey, namely, from Book K of the survey to create the variable as the proxy of remittance: 
1) What is the reason for a member of a household to move in/out of the household?

2) Where does the household member live now?

In order to construct the variable of remittance, researcher only collected the data from respondents that had these types of answers;

1. Household member moved out/in due to work

2. Household member moved to another area, not in the same area of respondents' households

From those answers, the researcher will have the migrant worker variable. A migrant worker is a member of a household that moved to another place to work. Thus, this migrant worker can be a good indicator of the availability of remittances since Indonesian people commonly send money back home (Adams Jr \& Cuecuecha, 2010).

\subsection{Econometric Model}

In order to run an empirical analysis, this research will employ the model introduced by Matano \& Ramos (2013). In their research, they use the probit estimation and the instrumental variable (IV) probit estimation. The instrumental variable (IV) is used to prevent the endogeneity of the remittance variable since the variable has a high possibility of being correlated with the error term and make the coefficient biased.

The correlation occurs because Indonesian households, with lower education and lower wealth characteristics, are more likely to have a migrant worker rather than households with higher education and greater wealth (Parinduri \& Thangavelu, 2011). In order to determine the instrumental variable, the researcher must find the variable that is correlated with the problematic independent variable but is not related to the dependent variable. Parinduri \& Thangavelu (2011) stated that the instrumental variable that can be employed for remittance is the variable of a district that has 'traditional migrant-sending' characteristic, meaning that the district typically has migrant workers who send remittances to their household of origin. The author claimed that remittances are correlated with the high 'traditional migrant-sending' districts because most of the migrant workers mostly come from certain provinces of Indonesia. People who wanted to be a migrant worker must have a decent knowledge of working outside their region, and the knowledge is mostly acquired from someone that has a close relationship with the person. Moreover, the increasing wealth of a household with a migrant worker will influence their neighbors and other family members by illustrating the benefits of migrant work. Thus, these neighbors and family members may, in turn, also become migrant workers because they wish to become wealthier. Furthermore, this variable did not validate the second rule of an instrumental variable since the variable of the traditional migrant household district is not correlated with educational achievement. Certainly, the traditional migrant household district variable fulfills two conditions of the 
instrumental variable, and the traditional migrant household district variable will only affect education achievement of the household through remittances.

The empirical model to determine the impact of remittances on school achievement of Indonesian households in this research follows the model of Matano \& Ramos (2013) Parinduri \& Thangavelu (2011), and McKenzie \& Rapoport (2011). These models joined the two regressions using Maximum Likelihood Estimation or Two-Stage Least Square probit estimation.

$\operatorname{Pr}\left(E_{i j}=1 / H_{j}, X_{i}, R_{i j}\right)=\varnothing\left(\alpha_{0}+\alpha_{1}\right.$ dRemittance (ddstrict) $+\alpha_{2}$ dsexcategory $+\alpha_{3}$ dMarital Status $+\alpha_{4}$ dWealth $+\alpha_{5}$ Household Head Age $+\alpha_{6}$ Household Head Education $+\varepsilon_{\mathrm{ij}}$ )

In their research, Matano \& Ramos (2013) organize two different estimation samples: a household with remittances formed the first sample, and the second sample was a household without remittances. The two samples also included household characteristics and individual characteristics. This research follows the same model. The first sample consists of 2,606 individuals that live in a household with a member who is a migrant worker. The second sample is a household without a migrant worker and consists of 18,472 individuals. After removing the missing values of all the variables, the samples decrease to 8,576 individuals.

The dependent variable in this study is educational attainment. The educational achievement variable is used in this research because education is still one of the main problems in Indonesia, especially in rural areas. Households in rural areas, and in some urban areas, have more concerns in increasing their household assets rather than the education of family members, due to the slow return on education

This research uses the household size variable to investigate the dependence of the household members on the income of the household. The increasing household size will increase the expenditure of the household. As the main focus of this paper is to investigate the impact of remittances as additional income for the family, measuring the size of the household will be an important part of the research.

The age of the household head is used to acknowledge the capacity and capability of the household head to maintain physical activity in order to maintain the position as he is the breadwinner in the household. The competency of the household head to find employment in a variety of types of job is the main reason this variable has been used. The age of the head of the household head has a strong relation to the household's ability to acquire assets. 
Marital status is an important factor that affects the educational achievement of the specific household. Matano \& Ramos (2013) found that the probability of having a higher education increases when the individual is single than if the individual is married. Furthermore, this finding proves that there is causal relation between marital status and education attainment and should be included in the model.

Table 1. Details Variable

\begin{tabular}{|c|c|c|c|}
\hline Number & Variable & Description & Question on IFLS 2014 \\
\hline 1 & Education & $\begin{array}{l}\text { Dummy variable of education } \\
\text { attainment currently being } \\
\text { pursued by individual I, taking } \\
\text { value } 1 \text { if the individual currently } \\
\text { studying in secondary school or } \\
\text { higher }\end{array}$ & - $\quad$ Book 3A (section ar06) \\
\hline 2 & Household Head Age & $\begin{array}{l}\text { The age of the household head in } \\
\text { one id household }\end{array}$ & $\begin{array}{ll}- & \text { Book K/control book } \\
& \text { section AR, column ARg } \\
\end{array}$ \\
\hline 3 & Marital Status & $\begin{array}{l}\text { Dummy variable of marital status } \\
\text { of household members, taking } \\
\text { the value } 1 \text { if the individual is } \\
\text { married }\end{array}$ & $\begin{array}{l}\text { Book } 3 \mathrm{~A} / \text { /ndividual } \\
\text { book, section cov, } \\
\text { column marstat }\end{array}$ \\
\hline 4 & $\begin{array}{l}\text { Household Head } \\
\text { Education }\end{array}$ & $\begin{array}{l}\text { Highest education level of } \\
\text { household's head }\end{array}$ & $\begin{array}{l}\text { Book } 3 \mathrm{~A} / \text { Individual } \\
\text { book, section DL, } \\
\text { column DL06 }\end{array}$ \\
\hline 5 & Sex category & Gender of the observation & $\begin{array}{l}\text { - } \quad \text { Book } 3 \mathrm{~A} / \text { Individual } \\
\text { book, section cov, } \\
\text { column sex }\end{array}$ \\
\hline 6 & Remittance & $\begin{array}{l}\text { Dummy variable of remittance } \\
\text { and taking the value if the } \\
\text { household receives remittances }\end{array}$ & $\begin{array}{l}\text { - } \\
\text { Book K/control book } \\
\text { Section AR, column 18f, } \\
\text { and 18i } \\
\text { Book 3B/Individual } \\
\text { book Section TF, } \\
\text { column tf05 } \\
\end{array}$ \\
\hline 7 & Wealth Variable & $\begin{array}{l}\text { Dummy variable of wealth and } \\
\text { taking the value of } 1 \text { if the } \\
\text { household has a Television }\end{array}$ & $\begin{array}{l}\text { - } \quad \text { Book 3A/individual } \\
\text { book Section } \\
\text { Household Asset, } \\
\text { column HR01 } \\
\end{array}$ \\
\hline 8 & District & $\begin{array}{l}\text { Dummy Variable of a traditionally } \\
\text { migrant-sending district with and } \\
\text { taking the value of } 1 \text { if the } \\
\text { household is in the following } \\
\text { provincial districts: Sukabumi, } \\
\text { Cianjur, and Indramayu district in } \\
\text { West Java province; Cilacap and } \\
\text { Wonsobo district in Central Java; } \\
\text { Kulon Progo district in } \\
\text { Yogyakarta; Malang, Kediri and } \\
\text { Ponorogo district in East Java; } \\
\text { and in the provinces; East Nusa } \\
\text { Tenggara, West Nusa Tenggara, } \\
\text { South Sulawesi and Lampung } \\
\text { Province }\end{array}$ & $\begin{array}{ll}- & \text { Book K/Control Book } \\
\text { Section SC, column } \\
\text { SC01, and SC02 }\end{array}$ \\
\hline
\end{tabular}

Wealth as a dummy variable is employed to determine the effect of a household's wealth on the education variable. It has been found that the greater 
the wealth of a household (along with the existence of a personal computer), there is the increased possibility that the household's family members will attend secondary school or higher (Matano \& Ramos, 2013). This variable also has a strong relationship to education, since the assets of the household will explain the variable of wealth, and this will be an important variable that will affect the ability of a household to send their children to school.

\section{Results and Discussion}

\subsection{Results}

Estimation result show in Table 2 the first column shows the probit regression in the assumption of there is no endogeneity on the variable; the regression is employed to the dependent variable which is children education attainment with remittance and other control variables. The result is significant in all control variables.

Table 2. The Results of Regression

\begin{tabular}{|c|c|c|c|}
\hline \multirow[t]{2}{*}{ Variable } & Probit regression & $\begin{array}{l}\text { IV probit } \\
\text { regression }\end{array}$ & $\begin{array}{l}\text { IV probit } \\
\text { regression }\end{array}$ \\
\hline & & $\begin{array}{l}\text { (Maximum } \\
\text { Likelihood } \\
\text { Estimation) }\end{array}$ & $\begin{array}{l}\text { ( } 2 \text { Stage Least } \\
\text { Square) }\end{array}$ \\
\hline \multirow[t]{2}{*}{ Remittance } & $0,437^{* * *}$ & $-1,995^{\star * \star}$ & $-2,866^{*}$ \\
\hline & $(0,00)$ & $(0,001)$ & $(0,056)$ \\
\hline \multirow[t]{2}{*}{ Sexcat } & $0,0835^{\star \star \star}$ & $0,177^{\star \star \star}$ & $0,254^{\star \star \star}$ \\
\hline & $(0,000)$ & $(0,000)$ & $(0,001)$ \\
\hline \multirow[t]{2}{*}{ Married_status } & $-1,181^{\star \star \star}$ & $-0,386^{\star \star *}$ & $-0,555^{\star \star *}$ \\
\hline & $(0,000)$ & $(0,000)$ & $(0,000)$ \\
\hline \multirow[t]{2}{*}{ Wealth } & $0,247^{\star \star \star}$ & $0,132^{\star \star *}$ & $0,1900^{* * *}$ \\
\hline & $(0,000)$ & $(0,000)$ & $(0,000)$ \\
\hline \multirow[t]{2}{*}{ Household Head Age } & $0,003^{* * *}$ & $0,002^{\star * *}$ & $0,0031^{\star * *}$ \\
\hline & $(0,000)$ & $(0,000)$ & $(0,000)$ \\
\hline \multirow[t]{2}{*}{ Household Head Education } & $-0,238^{\star \star \star}$ & $0,001^{\star \star \star}$ & $0,0016^{\star * *}$ \\
\hline & $(0,000)$ & $(0,000)$ & $(0,000)$ \\
\hline Observation & 89382 & 89382 & 89382 \\
\hline Wald test of exogenity & & 8,12 & 6,16 \\
\hline Prob>chi 2 & & 0,004 & 0,013 \\
\hline
\end{tabular}

*** Significant at 1\%; ** Sgnificant at 5\%; * Significant at 10\% 
The second column is the result of IV probit regression with Maximum Likelihood Estimation, numerous studies find that remittance is endogenous variable; therefore, instrumental variable is needed to make the result consistent. In the second column, some of the independent variable sign are different than the first column; this means the result of first column is inconsistent since there is endogenous regressors. The third column shows the result of the IV probit regression with 2-Stage Least Square estimation.

In the third column, all of the independent variable sign is same as the second column. The coefficient is different but it will not make a problem since the effect of the independent variable to dependent variable still the same.

Based on numerous previous researchers, which found that the remittance variable suffers from endogeneity and the estimation with Instrumental Variable will give consistent result. Thus, the second and third column will be discussed in the rest of this chapter. The result of regression shows that the sign of variable remittance is negative in both columns thus means that remittance decreasing the probability of children education outcome. The significance of the result on remittance variable is on $1 \%$ for MLE estimation and $10 \%$ for 2 SLS estimation, therefore the significance is different but both of estimators shows that the variable remittance influence probability of children obtaining higher education. For sex category variable the significance of the variable is at $1 \%$ significant level on both estimators, it means that sex category affects the probability of children obtaining higher education. The result sign of the sex category is positive it means the sex category increasing the probability of children obtaining higher education. Because the sex category is dummy variable and the base of sex category is female, it can be concluded that being a boy increasing the probability of obtaining higher education. Next variable is married status; in both of the estimation-married status have $1 \%$ significant level it means that the married status is affecting the probability of children obtaining higher education. The negative sign on the result shows that with being a marriage person will lower the probability of obtaining higher education than being unmarried. Moreover, for the wealth variable, significant at $1 \%$ level, the impact is positive on probability children obtaining higher education. The next variable is the age of household head also significant on $1 \%$ level on both estimator, the positive sign means that the possibilities of children obtaining higher education are increasing by more productive the household head is. The last variable is household's head education; the positive sign occurs in the result with $1 \%$ significant level. It means that the more education the household's head is the probability of children obtaining higher education is increasing. The last result to be mentioned is the wald-test of exogenity for both model is at below $5 \%$ significant level. It means that null hypothesis of wald-test is rejected and the variable remittances have endogeneity. 


\subsection{Discussion}

The result of this research is, remittance has negative impact on the probability children obtaining higher education. It means that remittance lowering the probability of obtaining higher education for children in the households. (Sarma, Parinduri, Sarma, \& Parinduri (2011) argue that the instructive result of education outcome depends on two important variables in the children life. The first variable is the children capacities on having education and the second variable is the parent inclinations for children tutoring. Migration of parents due to work will make the influence of the second variable is missing. The key variable of a scheme is the transitory status of parent influences on children capabilities (by mentally influencing the education outcome of the children by having parent absence from households) and the parent choices for children education (by expanding wage of the household and in this condition expanding the choices of children education). Remittance was claimed to loosening budget constraint of households and make parents affordable on purchasing more education for the children, therefore the disruption of migration and parent's absence may induce children to take higher education, it means the income effect will overpower by the physiological effect. As Nasir \& Salman Tariq, (2011) claims in his researches that the absence of the father in the community that mostly depends on father would have an enormous effect on education than the community that depends on both parents equally. Moreover, the negative impact of parental absence that affected children is the responsibilities of children in the house will increase due to the housework and non-labor work, this condition increases the opportunity cost of children schooling for higher education level.

Furthermore, McKenzie \& Rapoport, (2011) point out that incentive effect for children leaving in the migrant household is high, it means that the children from migrant households will most likely to be migrant worker compare to children from non-migrant households. This condition restrains the children from migrant households move into higher education. Finally, Khan \& Khan, (2016) argue that the remittance would have a negative effect if the family invested remittance on productive assets, such as family business than invest in education. They found that in the rural area, where self-business typically depends on family labor, the children induce to work at the family business and less likely going to higher education.

For other independent variable correlated with individual and household characteristic, all the independent variable is significantly proven. It means that all the independent variable affecting the probability of children obtaining higher education.

The two characteristic of household's head, household's head education and age of household head are increasing the probability of children obtaining higher education in Indonesia household. For a country like Indonesia, 
household's head has responsibilities to provide all households' need with only minor help from relatives. This condition makes the influence of household's head strongly affecting the outcome of the family, including education. Furthermore, parental education not only has a direct relationship with children education achievement, it has a larger scheme on generating children education outcome Ghanda \& Sunandachandira, (1985). Moreover, Panneer Selvam, (2013) find that moving to secondary school need higher cost, more time, and energy and higher parent education background will provide access to that higher need and less likely considering about education return in a short term. Finally, Watson \& Mcmahon, (2005) found that parents with education beyond secondary school or higher are able to give children assistant for higher education level and creating a better learning environment at home. That condition will increase the probability of children pursuing higher education level.

Age of Household Head also increases the probability of obtaining higher education for children in Indonesia households. The age of household's head is one of the factors to determine the productivity of the person. More productive the household's head age means more assets can be acquired to support education cost for children in the household's.

For sex category variable, Busquet, Barlet, Bocquier, \& De Vreyer (2013) find that in determine the education for children, gender is an important factor, in many cities in South Africa boys have a high probability of going to higher education than girls and also less likely to doing household chores. So, the variable sex category significantly affects the probability obtaining higher education for children.

In line with the result of several previous studies (Psacharopoulos, 1997; Ray, 2000) that claimed wealth has a significant and positive effect on child education, and reduce the probabilities of working children. The household's wealth will loosen the budget constraint of the family and increasing school enrolment. The result of wealth variable in this research also has a significant and positive effect. The effect of wealth measured by household asset has two effects on the opportunity cost of education. The first effect is discouraging effect, this means increasing on the asset will also increasing the opportunity cost of schooling. Agriculture asset is the example of the first effect, Kim \& Sherraden, (2010) on their research found that increasing on agriculture asset will increase the probabilities of children labor and this condition will increase the opportunity cost of schooling. The second effect is encouraging effect; this means that increasing on this asset will lowering opportunity cost of schooling. Kafle, Jolliffe, \& Winter-Nelson (2017) claimed that household asset such as electricity; water and bicycle may increase the efficiency of studying and increasing the return to school. 
Finally, for the last independent variable of married status, the result in this research is negative and significant. This result is in line with previous studies in Moldova by Matano \& Ramos (2013) that probabilities obtaining higher education is decreasing when the person is married than being single or married with foreign couple. Moreover, Field \& Ambrus, (2008) report that in Bangladesh the delayed time for married by one year will increase the year of schooling by 0.22 percent. Those studies conclude that marriage will decrease the probability of children obtaining higher education.

\section{Conclusions}

This study aims to investigate the effect of remittances on the probability of children at migrant households pursuing secondary education by using fifth wave of Indonesia Family Life Survey that collected in 2014. Using instrumental variable probit regression that employs dummy variable of remittance as the main factor and several control variables contains married status, sex category, the age of household's head, wealth, education of household's head, married status and district as an instrumental variable. The observation is consisting of 89,832 individual in the household roster from 1993 survey. The result shows that remittances decrease the probability of obtaining higher education on children of migrant households. The magnitude of the probability is different when using 2 Stage Least Square IV probit (2-SLS) and Maximum Likelihood IV probit (MLE), therefore the sign is the same. For another independent variable like the age of household's head, wealth, education household's head, and sex category have a positive influence on the probability of having higher education for children of the migrant household. On the other hand, marriage gives negative influence on probability of having higher education for children of migrant household.

The regression result can help Indonesian Government to establish a policy that hinders the possibilities of having lower education on children in the migrant household. The remittance that has negative and significant effect on probabilities children in the migrant household obtaining higher education indicates that the remittances spend on another productive asset such as business family asset or household asset rather than for education. Moreover, the migrant worker absence on migrant households affecting the motivation of children left behind. Further investigation is needed to determine a better channel for remittances to increase human capital formation. Furthermore, the policy affecting loosening budget constraint of households is not needed to increase the probability of having higher education for children in migrant households. One possible policy solution is providing a better job in the origin place of the migrant worker also ensure that migrant worker works on the formal sector with more worker welfare guarantee, thus the policy will decrease the number of migrant worker and children that left behind. 


\section{References}

Adams, R. H. (1991). The effects of international remittances on poverty, inequality, and development in rural Egypt (Vol. 86). Intl Food Policy Res Inst.

Adams, R. H., \& Page, J. (2005). Do international migration and remittances reduce poverty in developing countries? World Development, 33(10), 1645-1669.

Adams Jr, R. H., \& Cuecuecha, A. (2010). The economic impact of international remittances on poverty and household consumption and investment in Indonesia.

Blau, D. M. (1999). The effect of income on child development. The Review of Economics and Statistics, 81(2), 261-276.

Busquet, P. N. A., Barlet, M., Bocquier, P. N. L., \& De Vreyer, P. H. (2013). Urban Labor Market in Sub-Saharan Africa. (Santiago Pombo-Benjarano, Ed.). washington: World Bank. Retrieved from http://documents.worldbank.org/curated/en/494611468202805586/pd f/786800PUB0EPI10Box0377351B00PUBLIC0.pdf

Edwards, A. C., \& Ureta, M. (2003). International migration, remittances, and schooling: evidence from El Salvador. Journal of Development Economics, 72(2), 429-461.

Field, E., \& Ambrus, A. (2008). Early Marriage, Age of Menarche, and Female Schooling Attainment in Bangladesh. Journal of Political Economy (Vol. 116). https://doi.org/10.1086/593333

Ghanda, W. ., \& Sunandachandira. (1985). A comparative Study of the Adolescent Boys and Girs in Relation to Their Attitudes Towards School Adjustment and Scholastic Achievment. The Indian Journal of Community Guidance Service, 2 and 3.

Hanson, G. H., \& Woodruff, C. (2003). Emigration and Educational Attainment in Mexico. Retrieved from http://www.childmigration.net/files/Hanson_2003.pdf

Hill, M. S., \& Duncan, G. J. (1987). Parental family income and the socioeconomic attainment of children. Social Science Research, 16(1), 39-73.

IFAD in Indonesia. (n.d.). Retrieved October 20, 2017, from https://operations.ifad.org/web/ifad/operations/country/home/tags/in donesia

Indonesia Remittances | 2005-2017 | Data | Chart | Calendar | Forecast. (n.d.). Retrieved October 20, 2017, from

https://tradingeconomics.com/indonesia/remittances

Kafle, K., Jolliffe, D., \& Winter-Nelson, A. (2017). Do Different Types of Assets Have Differential Effects on Child Education? Evidence from Tanzania. Retrieved from

http://documents.worldbank.org/curated/en/423981495472619176/pdf MPS8071.pdf

Khan, S. U., \& Khan, M. J. (2016). The Impact of Remittances on Child Education 
in Pakistan. (C) Lahore School of Economics.

Kim, Y., \& Sherraden, M. (2010). Do Parental Assets Matter for Children's Educational Attainment?: Evidence from Mediation Tests. Retrieved from https://csd.wustl.edu/Publications/Documents/WP10-40.pdf

Matano, A., \& Ramos, R. (2013). Remittances and educational outcomes: evidence for Moldova. SEARCH working paper WP3/10. April 2013. http://www. ub. edu/searchproject/wpcontent/uploads/2013/05/SEARCH-WP-3.10. pdf.

McKenzie, D., \& Rapoport, H. (2011). Can migration reduce educational attainment? Evidence from Mexico. Journal of Population Economics, 24(4), 1331-1358.

Nasir, M., \& Salman Tariq, M. (2011). The Effect of Foreign Remittances on Schooling: Evidence from Pakistan.

Nguyen, T., \& Purnamasari, R. (2011). Impacts of international migration and remittances on child outcomes and labor supply in Indonesia: How does gender matter?

Panneer Selvam, S. K. (2013). A study on relationship between parental education and student achievement. Education Research Journal, 3(3), 75-82. Retrieved from http://www.resjournals.com/ERJ

Parinduri, R. A., \& Thangavelu, S. M. (2011). Impact of remittances on human capital development of children in Indonesian household. Preliminary Draft.

Psacharopoulos, G. (1997). Child labor versus educational attainment Some evidence from Latin America. Journal of Population Economics, 10(4), 377-386.

Ray, R. (2000). Analysis ofchild Labour in Peru and Pakistan: A Comparative Study. Journal of Population Economics, 13(1), 3-19.

Resosudarmo, B. P., \& Suryadarma, D. (2014). The Impact of Childhood Migration on Educational Attainment: Evidence from rural-urban migrants in Indonesia. Asian Population Studies, 10(3), 319-333.

Salas, V. B. (2014). International remittances and human capital formation. World Development, 59, 224-237.

Sarma, V., Parinduri, R., Sarma, V. J., \& Parinduri, R. A. (n.d.). M P RA What happen to children's education when their parents emigrate? Evidence from Sri Lanka What Happen to Children's Education when Their Parents Emigrate? Evidence from Sri Lanka. Retrieved from https://mpra.ub.unimuenchen.de/52278/

Todaro, M. P. (1969). A model of labor migration and urban unemployment in less developed countries. The American Economic Review, 59(1), 138148.

Watson, M., \& Mcmahon, M. (2005). Children's career development: A research review from a learning perspective. Journal of Vocational Behavior, 67, 119-132. https://doi.org/10.1016/j.jvb.2004.08.011 
Yang, D., Charles, K., Das, J., Dinardo, J., Dang, H.-A., Do, Q.-T., ... Schiff, M. (n.d.). International Migration, Remittances and Household Investment: Evidence From Philippine Migrants' Exchange Rate Shocks*. Retrieved from http://citeseerx.ist.psu.edu/viewdoc/download?doi=10.1.1.205.6017\&rep=rep1\& type $=$ pdf

Zhao, Q., Yu, X., Wang, X., \& Glauben, T. (2014). The impact of parental migration on children's school performance in rural China. China Economic Review, 31, 43-54. 